\title{
Abbreviated List of Secondary Sources
}

BABB Lawrence Babb. Sanity in Bedlam: A Study of Robert Burton's "Anatomy of Melancholy." East Lansing: Michigan State University Press, 1959.

Colrs Rosalie Colie. Paradoxia Epidemica: The Renaissance Tradition of Paradox. Princeton University Press, 1966.

Finlay Daniel Henry Finlay. "A Study of Form in the Anatomy of Melancholy." Ph.D. diss., University of Virginia, 1966.

Fish Stanley E. Fish. Self-Consuming Artifacts: The Experience of Seventeenth-Century Literature. Berkeley, Los Angeles, London: University of California Press, 1972.

Hallwachs Robert G. Hallwachs. "Additions and Revisions in the Second Edition of Burton's Anatomy of Melancholy." Ph.D. diss., Princeton, 1934.

KING James Roy King. Studies in Six 17th Century Writers. Athens: University of Ohio Press, 1966. 
Lyons Bridget Gellert Lyons. Voices of Melancholy: Studies in Literary Treatments of Melancholy in Renaissance England. London: Routledge and Kegan Paul, 1971.

Murller William Mueller. The Anatomy of Robert Burton's England. Berkeley and Los Angeles: University of California Press, 1952.

Nochmson Richard L. Nochimson. "Robert Burton: A Study of the Man, His Work, and His Critics." Ph.D. diss., Columbia, 1967.

OsLer Sir William Osler, Edward Bensly, and others. "Robert Burton and the Anatomy of Melancholy." Ed. F. Madan. Oxford Bibliographical Society Proceedings and Papers, 1 (1927).

Smon Jean Robert Simon. Robert Burton (15771640) et L'Anatomie de la Mélancolie. Paris: Didier, 1964.

WeBrer Joan Webber. The Eloquent ' $T$ ': Style and Self in Seventeenth-Century Prose. Madison: University of Wisconsin Press, 1968. 
